\title{
Effect of Initial Periodontal Treatment on Cardiovascular Risk Markers in Patients with Severe Chronic Periodontitis
}

\section{Şiddetli Kronik Periodontitisli Hastalarda Başlangıç Periodontal Tedavinin Kardiyovasküler Risk Belirteçleri Üzerindeki Etkisi}

\author{
(D) Meltem Karşıyaka Hendek ${ }^{1}$, (1) Ebru Olgun ${ }^{1}$, (1) Üçler Kısa ${ }^{2}$ \\ ${ }^{1}$ Kırıkkale University Faculty of Dentistry, Department of Periodontology, Kırıkkale, Turkey \\ ${ }^{2}$ Kırıkkale University Faculty of Medicine, Department of Biochemistry, Kırıkkale, Turkey
}

Keywords

Cardiovascular disease, initial periodontal treatment, asymmetric dimethylarginine, endothelial nitric oxide synthase, homocysteine, monocyte chemoattractant protein-1

Anahtar Kelimeler

Kardiyovasküler hastalık, başlangıç periodontal tedavi, asimetrik dimetil arjinin, endotelyal nitrik oksit sentaz, homosistein, monosit kemoatraktan protein-1

Received/Geliş Tarihi : 03.07.2018 Accepted/Kabul Tarihi : 25.10.2018

doi:10.4274/meandros.galenos.2018.58661

Address for Correspondence/Yazışma Adresi: Meltem Karşıyaka Hendek DDS, PhD, Kırıkkale University Faculty of Dentistry, Department of Periodontology, Kırıkkale, Turkey Phone : +90 3182244927

E-mail :mltmkrsyk@yahoo.com

ORCID ID: orcid.org/0000-0003-1518-4159

(C) Meandros Medical and Dental Journal, Published by Galenos Publishing House.

This is article distributed under the terms of the Creative Commons Attribution NonCommercial 4.0 International Licence (CC BY-NC 4.0).

\begin{abstract}
Objective: The aim of the study was to determine the influence of initial periodontal treatment in patients with severe chronic periodontitis on inflammatory markers related to risk for cardiovascular diseases.

Materials and Methods: A total of 80 non-smokers with systemically healthy, including 40 patients (29 female, 11 male) with severe chronic periodontitis (test group) and 40 periodontally healthy participants (21 female, 19 male) (control group) were included into the present study. The probing depth, clinical attachment level, plaque index, gingival index and blood samples were collected at baseline and at the $3^{\text {rd }}$ months after treatment and the serum levels of asymmetric dimethylarginine (ADMA), endothelial nitric oxide synthase (eNOS), homocysteine (Hcy), monocyte chemoattractant protein-1 (MCP-1) were determined with enzyme-linked immunosorbent assay.

Results: At baseline, all clinical periodontal parameters were significantly higher in the chronic periodontitis group than in the periodontally healthy group $(p<0.05)$. After the initial periodontal treatment, in the test group, all of the clinical periodontal parameters showed a significant decrease compared to the baseline values $(p<0.05)$. At baseline, ADMA, Hcy and MCP-1 levels were significantly higher in the test group than in the control group $(p<0.05)$, and after treatment ADMA and MCP-1 levels showed a significant decrease whereas eNOS level showed significant increase $(\mathrm{p}<0.05)$.

Conclusion: It was observed that initial periodontal treatment in patients with severe chronic periodontitis has positive effects on cardiovascular risk markers.
\end{abstract}

Öz

Amaç: Bu çalışmanın amacı, şiddetli kronik periodontitisli hastalarda kardiyovasküler hastalık ile ilişkili enflamatuvar belirteçler üzerinde başlangıç periodontal tedavinin etkisini belirlemektir.

Gereç ve Yöntemler: Bu çalışmaya, sistemik olarak sağlıklı, şiddetli kronik periodontitisli 40 hasta (29'u kadın, 11'i erkek) (test grubu) ve periodontal olarak sağlıklı 40 birey (21 kadın, 19 erkek) (kontrol grubu) olmak üzere toplam da 80 sigara içmeyen birey dahil edildi. Sondalama derinliği, klinik ataşman seviyesi, plak indeksi, gingival indeks ve kan örnekleri tedavi öncesinde ve tedaviden sonraki 3. 
ayda toplandı ve asimetrik dimetilarginin (ADMA), endotelyal nitrik oksit sentaz (eNOS), homosistein (Hcy) ve monosit kemoatraktan protein-1 (MCP-1) serum seviyeleri enzim-bağlı immünosorbent analiziyle belirlendi.

Bulgular: Başlangıçta, tüm klinik periodontal parametreler kronik periodontitisli grupta periodontal olarak sağlıklı gruba göre anlamlı derecede yüksek bulundu $(p<0.05)$. Başlangıç periodontal tedaviden sonra, test grubunda, tüm klinik periodontal parametreler, başlangıç değerleri ile karşılaştırıldığında anlamlı bir düşüş gösterdi $(p<0.05)$. Başlangıı̧ta test grubunda ADMA, Hcy ve MCP-1 düzeyleri kontrol grubuna göre anlamlı olarak yüksekti $(p<0.05)$, tedavi sonrası ADMA ve MCP-1 düzeylerinde anlamlı azalma, eNOS seviyesinde anlamlı artış saptandı $(\mathrm{p}<0.05)$.

Sonuç: Şiddetli kronik periodontitisli hastalarda başlangıç periodontal tedavinin kardiyovasküler risk belirteçleri üzerinde olumlu etkileri olduğu gözlendi.

\section{Introduction}

Periodontitis is a chronic infectious disease caused by the microbial dental plaque. The microorganisms in the subgingival environment and their products can enter the periodontal tissues and circulation through the epithelium, which is mostly ulcerated and impaired in integrity. While periodontal tissues give an immunoinflammatory response to these bacteria and their products, the systemic effects of these agents also result in a major vascular response (1). Recently, there has been an increased relevance between periodontitis and cardiovascular conditions. Bacteraemia caused by chronic infections and host-induced inflammatory products may cause to susceptibility to coronary heart disease by damaging of vascular endothelium. The damaged vessel endothelium is unable to function normally and endothelial dysfunction occurs (2). The clinical significance of endothelial dysfunction has been emphasized in study with increased risk of cardiovascular disease (CVD) in patients with endothelial dysfunction in coronary and peripheral arteries (3). Abundant evidence supports that periodontal disease-induced infections are potential risk factors for CVD $(2,4)$. It has been shown that low-level chronic systemic inflammation has associated with undesirable cardiovascular outcomes (5). It has been shown that periodontal pathogens induce platelet aggregation, foam cell formation and atheroma development (6). Inflammation induces atheroma formation in major elastic arteries by damaging endothelial function. It leads to susceptibility to thrombotic and embolic conditions by disrupting the integrity of the arterial plaque and creating unstable plaque vascular spaces (7). Therefore, periodontitis, like many infectious diseases, is considered a risk factor for CVDs (8-10). Interventional trials suggest that periodontal therapy, in general, results in significant reduction of systemic marker levels $(11,12)$, especially in patients with systemic diseases such as CVD (12).

Nitric oxide (NO) has some functions in cardiovascular system, such as regulation of vasomotor tonus, modulation of myocardial contraction, platelet activation with control of cell proliferation, inhibition of adhesion and aggregation. NO is synthesized by nitric oxide synthases (NOS), which have three isoforms. Endothelial nitric oxide synthase (eNOS) enzyme, which is constituvely formulated from endothelial cells, has important roles in the cardiovascular system (13). Asymmetric dimethylarginine (ADMA) inhibits NO synthesis and causes vasospasm and endothelial dysfunction and is considered a risk factor for the development of coronary artery disease (14). Homocysteine ( $\mathrm{Hcy}$ ) is a sulfur-containing amino acid generated as an intermediate product in methionine metabolism. Increased levels of $\mathrm{Hcy}$ have been associated with a number of vascular complications, and due to this fact hyperhomocysteinemia has been classified as an independent risk factor for atherosclerosis and CVDs (15-17). Monocyte chemoattractant protein (MCP)-1 is one of the chemokines that contributes to the inflammatory process in atherosclerosis. It provides monocyte migration to the region of atherosclerotic lesions (18).

There is limited data on the possible effect of initial periodontal treatment on the systemic biomarkers of CVDs in systemically healthy individuals with severe chronic periodontitis (CP). Therefore, the objectives of the study were (1) to determine the levels of serum ADMA, eNOS, Hcy and MCP-1 in periodontal health and disease; (2) to assess the effect of initial periodontal treatment on these markers in patients with severe chronic periodontitis.

The hypothesis of this study was that severe chronic periodontitis adversely affects the levels of cardiovascular risk markers in serum in systemically 
healthy individuals and initial periodontal treatment modifies these levels, favorably.

\section{Materials and Methods}

\section{Study Population}

40 patients ( 29 female, 11 male) with severe chronic periodontitis as a test group and 40 patients (21 female, 19 male) with periodontally healthy as a control group were enrolled in the study from Kırıkkale University Faculty of Dentistry, Department of Periodontology, Kırıkkale. Patients were excluded who: 1) had any systemic disease; 2) received any periodontal treatment within the previous year; 3 ) received any drugs such as nonsteroidal anti-inflammatory drugs, systemic steroids, immunosuppressants, contraceptives, hormone drugs, anticoagulants, cholesterol regulating drugs, systemic antibiotics, antioxidants within the previous 3 months; 4 ) were pregnant or lactating; 5 ) consumed alcohol; or 6) were smoker. For consecutive patients fulfilling the inclusion criteria, the purpose and procedures were fully explained and they were asked to participate in the study. Patients were entered into the study only after verbal consent was obtained from each subject. The study was approved by the Ethics Committee of Kırıkkale University Kırıkkale, Turkey. (date: 06.07.2015, no: 19/07)

\section{Study Groups}

At the screening visit, a full-mouth periodontal evaluation was performed in order to assess the inclusion/exclusion criteria. Patients with severe chronic periodontitis had teeth with alveolar bone loss, $\geq 2$ non-adjacent sites per quadrant with clinical attachment level (CAL) $\geq 6 \mathrm{~mm}$ and bleeding on probing. The individuals with $C A L \leq 2$, no history of gingival inflammation and radiographic alveolar bone loss were included as the periodontally healthy group. The total number of teeth for each participant was $\geq 20$.

\section{Clinical Periodontal Parameters}

One masked examiner (E.O.) assessed the periodontal status of each patient at baseline and three months post-treatment. Clinical periodontal measurements including plaque index (19), gingival index (20), probing depth (PD) (measured from gingival margin to pocket bottom) and CAL (measured from cemento-enamel junction to pocket bottom) were taken from six sites of the teeth. Intra-examiner calibration was performed twice, before and during the study, by assessing PD and CAL in duplicate, with a degree of agreement within $\pm 1 \mathrm{~mm}$ higher than $85 \%$ at both tests. Under local anesthesia, within 14 days, initial periodontal treatment (scaling + root planing + polishing) was performed in patients with $\mathrm{CP}$ with manual and ultrasonic devices and standardized oral hygiene instructions including methods of toothbrushing and interdental cleaning were also given to each one. During the study period, professional plaque control was performed monthly. Scaling and oral hygiene were carried out in periodontally healthy groups. All periodontal clinical measurements were repeated at baseline and the $3^{\text {rd }}$ month after the treatment in the test group and at baseline in periodontally healthy group.

\section{Collection and Analysis of Blood Samples}

Five $\mathrm{mL}$ venous blood samples were drawn in biochemical tubes including gel to prevent the potentiality of mixture of serum and plasma. The samples were centrifuged at $5.000 \mathrm{rpm}$ for 10 minutes and stored at $-80^{\circ} \mathrm{C}$ until analysis. Serum samples were taken in the test group at baseline and at the $3^{\text {rd }}$ month after treatment and in the control group at baseline. ADMA, eNOS, Hcy and MCP-1 in serum samples were measured by enzyme-linked immunosorbent assay using commercial kits according to the manufacturers' instructions.

\section{Statistical Analysis}

To achieve $99 \%$ power and detect differences between groups, 40 participants in each group were required. At the end of the study, a post hoc analysis was also performed and $98 \%$ power was detected with a sample size of 28 for test group. The Shapiro-Wilk test was used to examine the normality of data distribution. The median (interquartile range) values were used for the non-normally distributed data. Differences between groups were analyzed by Mann-Whitney $U$ test and intra group differences were analyzed by Wilcoxon test. Software was used for statistical analysis. A $p$ value $<0.05$ was considered significant.

\section{Results}

\section{Demographic and Clinical Findings}

Initial periodontal treatment was performed on 40 individuals with CP. At the $3^{\text {rd }}$ month, twelve 
participants were lost during follow-up and 28 patients with CP completed all visits of the study. The demographical and periodontal parameters of the study participants are presented in Table 1 . Age and gender distributions were not significant between the groups $(p>0.05)$. All clinical periodontal parameters were significantly higher in the chronic periodontitis group than in the periodontally healthy group $(p<0.05)$. In the test group, all of the clinical periodontal parameters after the initial periodontal treatment showed a statistically significant decrease compared to the baseline values $(p<0.05)$ (Table 1$)$.

\section{Laboratory Findings}

The ADMA, eNOS, Hcy and MCP-1 levels of the groups are shown in Table 2. ADMA, Hcy and MCP-1 levels in the test group were significantly higher than the control group, and ADMA and MCP-1 levels after treatment showed a significant decrease whereas eNOS level increased significantly $(p<0.05)$.

\section{Discussion}

In this study, the effect of initial periodontal treatment on cardiovascular risk markers was evaluated in patients with severe chronic periodontitis. According to this study, serum ADMA and MCP-1 levels significantly decreased with initial periodontal treatment and eNOS level significantly increased.

ADMA is an amino acid derivative synthesized endogenously by the methylation of arginine residues in proteins (21). ADMA has increasingly become a prevalent molecule, which is being intensively studied for use in clinical diagnosis. ADMA reduces ventricular contraction and heart rate, and its levels increase in cardiac failure (22). The mechanism of endothelial dysfunction caused by ADMA is due to the increase in vascular superoxide levels and decrease in the availability of vascular NO (23). Oxidative stress reduces the activity of the enzyme responsible for ADMA catabolism and thus increases the blood level while ADMA degradation is reduced (24). Therefore, in many degenerative diseases that increase oxidative stress, ADMA level is found to be increased. There are studies showing that ADMA plays a role not only in CVDs but also in the pathogenesis of renal diseases, type 2 diabetes mellitus and preeclampsia $(25,26)$. It has shown that an increase in reactive oxygen

Table 1. Demographic and clinical periodontal parameters in the study groups [median (interquartile range)]

\begin{tabular}{|c|c|c|c|}
\hline & $\begin{array}{l}\text { Control group } \\
(n=40)\end{array}$ & $\begin{array}{l}\text { Test group } \\
(n=40)\end{array}$ & $\begin{array}{l}\text { Test group } \\
\text { (post-treatment; } \mathbf{n = 2 8} \text { ) }\end{array}$ \\
\hline Age (year) & $36[6]$ & 38.5 [7] & - \\
\hline Gender (F/M) & $21 / 19$ & $29 / 11$ & - \\
\hline PD (mm) & $2.25[0.84]$ & $5.70[1.10]^{a, b}$ & $3.68[0.76]$ \\
\hline CAL $(\mathrm{mm})$ & $0.00[1.08]$ & $6.26[1.17]^{a, b}$ & $4.24[0.36]$ \\
\hline PI & $0.33[0.18]$ & $2.19[0.46]^{a, b}$ & $0.51[1.01]$ \\
\hline GI & $0.33[0.26]$ & $2.07[0.33]^{a, b}$ & $0.66[0.10]$ \\
\hline \multicolumn{4}{|c|}{$\begin{array}{l}\text { PD: Probing depth, CAL: Clinical attachment level, PI: Plaque index, GI: Gingival index, F: Female, M: Male } \\
\text {, } p<0.05 \text {, difference between test and control groups } \\
\text { ', } p<0.05 \text {, difference before and after treatment }\end{array}$} \\
\hline
\end{tabular}

Table 2. Serum asymmetric dimethylarginine, endothelial nitric oxide synthase, homocysteine, monocyte chemoattractant protein-1 concentrations in the study groups [median (interquartile range)]

\begin{tabular}{|c|c|c|c|}
\hline & $\begin{array}{l}\text { Control group } \\
(n=40)\end{array}$ & $\begin{array}{l}\text { Test group } \\
(n=40)\end{array}$ & $\begin{array}{l}\text { Test group } \\
\text { (post-treatment; } n=28 \text { ) }\end{array}$ \\
\hline ADMA (pg/mL) & 89.34 [65.13] & $158.24[147.74]^{a, b}$ & 104.54 [49.19] \\
\hline eNOS (pg/mL) & 183.58 [90.19] & $197.45[129.97]^{\mathrm{b}}$ & $286.29[80.23]$ \\
\hline Hcy (nmol/mL) & $15.28[4.32]$ & $17.09[8.68]^{a}$ & $17.22[5.91]$ \\
\hline MCP-1 (ng/mL) & 26.44 [18.97] & $34.32[23.22]^{a, b}$ & 28.06 [24.66] \\
\hline \multicolumn{4}{|c|}{$\begin{array}{l}\text { ADMA: Asymmetric dimethylarginine, eNOS: Endothelial nitric oxide synthase, Hcy: Homocysteine, MCP: Monocyte chemoattractant protein } \\
\text { a, } p<0.05 \text {, difference between test and control groups } \\
\text { b, } p<0.05 \text {, difference before and after treatment }\end{array}$} \\
\hline
\end{tabular}


species (ROS) may cause endothelial dysfunction (27). The activation of endothelial cells induced by proinflammatory cytokines produces ROS that inactivate NO. Therefore, increase in NO inactivation and decrease in antioxidant system caused by overproduction of ROS may cause endothelial dysfunction in patients with periodontitis. Antoniades et al. (28) have shown that oxidative stress and pro-inflammatory cytokines increase ADMA level and therefore cause endothelial dysfunction. In our study, serum ADMA concentration was higher in patients with chronic periodontitis than in periodontally healthy subjects, and there was a decrease in ADMA concentration from baseline with initial periodontal treatment. These results may be related to the fact that periodontitis, which is known to cause oxidative stress, may have also increased ADMA levels.

NO is secreted by the endothelium, and it has protective effects on vascular structure and function. Inhibition of smooth muscle proliferation, prevention of leukocyte adhesion, and platelet aggregation are among these effects. Damage to the endothelium causes a decrease in NO levels, thus leading to impairment in vascular function. In the absence of NO, proliferation is observed in the vascular smooth muscles and the elasticity of the vessel wall is reduced; hence, loss of flow-dependent vasodilatation occurs (29). In endothelial cells, NO is produced by endothelial NOS. ADMA inhibits NOS in humans and causes a decrease in NO levels, resulting in endothelial dysfunction (30). The increased level of eNOS with periodontal treatment in our study may have occurred due to decreased ADMA concentration.

$\mathrm{Hcy}$ is a sulfur-containing amino acid and is methylated to methionine as a metabolite. Elevated plasma Hcy levels are associated with oxidative damage to the vascular endothelium, vascular smooth muscle proliferation, and lipid peroxidation, and may result in peripheral arterial diseases and atherothrombosis (31). Possible mechanisms include the production of pro-inflammatory cytokines such as interleukins and TNF-alpha from inflammatory periodontal tissues. These mediators may initiate an inflammatory cascade with the potential to disrupt $\mathrm{Hcy}$ homeostasis and thereby increase plasma Hcy concentrations (32). In a case-control study, plasma Hcy levels were found to be significantly higher in patients with periodontitis than in periodontally healthy subjects (33). In our study, high serum Hcy concentration in the test group compared with the control group can be explained by the presence of periodontitis, which leads to a systemic inflammatory process.

MCP-1 is a chemokine involved in cell migration throughout the inflammation process (34) and secreted from endothelial cells and vascular smooth muscle cells to attract circulating monocytes to the inflammation site (35). It is known that MCP-1 is associated with oral infections, owing to its monocyte chemotactic abilities (36). Previous studies have shown that MCP-1 expression is high in gingival biopsies from diseased periodontal areas (37) and that MCP-1 levels are high in gingival crevicular fluids of patients with periodontitis (38). In our study, serum MCP-1 concentration was found to be significantly higher in patients with chronic periodontitis than periodontally healthy patients, and a significant decrease was observed in the test group after treatment compared with baseline values, indicating that MCP-1 can be used as a marker for CVD in patients with periodontitis.

Unknown inflammatory conditions might have an effect on the observed cardiovascular risk biomarker levels. The lack of information on the individuals' cardiac or comprehensive medical profile represents a limitation of the study.

\section{Conclusion}

Increased of periodontal inflammation may indicate raised levels of systemic cardiovascular risk biomarkers in systemically healthy subjects and initial periodontal treatment may but not totally reverse this condition. Proper periodontal management should be suggested to improve the systemic health conditions of patients. Further studies can be performed with a group consisted of CVDs to confirm the importance of periodontal treatment.

\section{Acknowledgements}

The Scientific Research Project Fund of Kırıkkale University (project number: 2015/029) supported this research.

Ethics

Ethics Committee Approval: The study was approved by the Ethics Committee of Kırıkkale University Kırıkkale, Turkey. (date: 06.07.2015, no: 19/07) 
Informed Consent: Patients were entered into the study only after verbal consent was obtained from each subject.

Peer-review: Externally and internally peerreviewed.

\section{Authorship Contributions}

Surgical and Medical Practices: M.K.H., E.O., Concept: M.K.H., E.O., Design: M.K.H., E.O., Data Collection or Processing: M.K.H., E.O., Analysis or Interpretation: M.K.H., E.O., Ü.K., Literature Search: M.K.H., E.O., Ü.K., Writing: M.K.H., E.O., Ü.K.

Conflict of Interest: The authors declare that they have no conflict of interest.

Financial Disclosure: The authors declared that this studyreceived no financial support.

\section{References}

1. Tatakis DN, Kumar PS. Etiology and pathogenesis of periodontal diseases. Dent Clin North Am 2005; 49: 491-516.

2. Beck JD, Offenbacher S. Systemic effects of periodontitis: epidemiology of periodontal disease and cardiovascular disease. J Periodontol 2005; 76: 2089-100.

3. Heitzer T, Schlinzig T, Krohn K, Meinertz T, Münzel T. Endothelial dysfunction, oxidative stress, and risk of cardiovascular events in patients with coronary artery disease. Circulation 2001; 104: 2673-8.

4. Khader YS, Albashaireh ZS, Alomari MA. Periodontal diseases and the risk of coronary heart and cerebrovascular diseases: a meta-analysis. J Periodontol 2004; 75: 1046-53.

5. Loos BG, Craandijk J, Hoek FJ, Wertheim-van Dillen PM, van der Velden $U$. Elevation of systemic markers related to cardiovascular diseases in the peripheral blood of periodontitis patients. J Periodontol 2000; 71: 1528-34.

6. Lalla E, Lamster IB, Hofmann MA, Bucciarelli L, Jerud AP, Tucker $S$, et al. Oral infection with a periodontal pathogen accelerates early atherosclerosis in apolipoprotein E-null mice. Arterioscler Thromb Vasc Biol 2003; 23: 1405-11.

7. Hansson GK, Robertson AK, Söderberg-Nauclér C. Inflammation and atherosclerosis. Annu Rev Pathol 2006; 1: 297-329.

8. Tonetti MS, Van Dyke TE; working group 1 of the joint EFP/AAP workshop. Periodontitis and atherosclerotic cardiovascular disease: consensus report of the Joint EFP/AAP Workshop on Periodontitis and Systemic Diseases. J Periodontol 2013; 84: 24-9.

9. Jeftha $A$, Holmes $H$. Periodontitis and cardiovascular disease. SADJ 2013; 68: 60, 62-3.

10. Bartova J, Sommerova P, Lyuya-Mi Y, Mysak J, Prochazkova J, Duskova J, et al. Periodontitis as a risk factor of atherosclerosis. J Immunol Res 2014; 2014: 636893.

11. Bokhari SA, Khan AA, Butt AK, Azhar M, Hanif M, Izhar M, et al. Non-surgical periodontal therapy reduces coronary heart disease risk markers: a randomized controlled trial. J Clin Periodontol 2012; 39: 1065-74.

12. Teeuw WJ, Slot DE, Susanto H, Gerdes VE, Abbas F, D'Aiuto F, et al. Treatment of periodontitis improves the atherosclerotic profile: a systematic review and meta-analysis. J Clin Periodontol 2014; 41: 70-9.

13. Carnicer R, Crabtree MJ, Sivakumaran V, Casadei B, Kass DA. Nitric oxide synthases in heart failure. Antioxid Redox Signal 2013; 18: 1078-99.

14. Böger $\mathrm{RH}$. Asymmetric dimethylarginine: understanding the physiology, genetics, and clinical relevance of this novel biomarker. Proceedings of the 4th International Symposium on ADMA. Pharmacol Res 2009; 60: 447.

15. Wang $B R$, Ou Z, Jiang T, Zhang YD, Zhao HD, Tian YY, et al. Independent Correlation of Serum Homocysteine with Cerebral Microbleeds in Patients with Acute Ischemic Stroke due to LargeArtery Atherosclerosis. J Stroke Cerebrovasc Dis 2016; 25: 274651.

16. Zhang HP, Wang YH, Cao CJ, Yang XM, Ma SC, Han XB, et al. A regulatory circuit involving miR-143 and DNMT3a mediates vascular smooth muscle cell proliferation induced by homocysteine. Mol Med Rep 2016; 13: 483-90.

17. Cioni G, Marcucci R, Gori AM, Valente S, Giglioli C, Gensini GF, et al. Increased homocysteine and lipoprotein(a) levels highlight systemic atherosclerotic burden in patients with a history of acute coronary syndromes. J Vasc Surg 2016; 64: 163-70.

18. Lin J, Kakkar V, Lu X. Impact of MCP-1 in atherosclerosis. Curr Pharm Des 2014; 20: 4580-8.

19. Silness J, Löe H. Periodontal disease in pregnancy. II. Correlation between oral hygiene and periodontal condition. Acta Odontol Scand 1964; 22: 121-35.

20. Löe $\mathrm{H}$, Silness J. Periodontal disease in pregnancy. I. Prevalence and severity. Acta Odontol Scand 1963; 21: 533-51.

21. Vallance $P$, Leiper J. Cardiovascular biology of the asymmetric dimethylarginine:dimethylarginine dimethylaminohydrolase pathway. Arterioscler Thromb Vasc Biol 2004; 24: 1023-30.

22. Saitoh M, Osanai T, Kamada T, Matsunaga T, Ishizaka $H$, Hanada $\mathrm{H}$, et al. High plasma level of asymmetric dimethylarginine in patients with acutely exacerbated congestive heart failure: role in reduction of plasma nitric oxide level. Heart Vessels 2003; 18: 177-82.

23. Sydow K, Schwedhelm E, Arakawa N, Bode-Böger SM, Tsikas $D$, Hornig $B$, et al. and oxidative stress are responsible for endothelial dysfunction in hyperhomocyst(e)inemia: effects of L-arginine and B vitamins. Cardiovasc Res 2003; 57: 244-52.

24. Landim MB, Casella Filho A, Chagas AC. Asymmetric dimethylarginine (ADMA) and endothelial dysfunction: implications for atherogenesis. Clinics (Sao Paulo) 2009; 64: 4718.

25. Krzyzanowska K, Mittermayer F, Shnawa N, Hofer M, Schnabler $\mathrm{J}$, Etmüller $\mathrm{Y}$, et al. Asymmetrical dimethylarginine is related to renal function, chronic inflammation and macroangiopathy in patients with Type 2 diabetes and albuminuria. Diabet Med 2007; 24: 81-6. 
26. Fickling SA, Williams D, Vallance $P$, Nussey SS, Whitley GS. Plasma concentrations of endogenous inhibitor of nitric oxide synthesis in normal pregnancy and pre-eclampsia. Lancet 1993; 342: 242-3.

27. Cai H, Harrison DG. Endothelial dysfunction in cardiovascular diseases: the role of oxidant stress. Circ Res 2000; 87: 840-4.

28. Antoniades C, Tousoulis D, Marinou K, Vasiliadou C, Tentolouris C, Bouras G, et al. Asymmetrical dimethylarginine regulates endothelial function in methionine-induced but not in chronic homocystinemia in humans: effect of oxidative stress and proinflammatory cytokines. Am J Clin Nutr 2006; 84: 781-8.

29. Cooke JP. ADMA: its role in vascular disease. Vasc Med 2005; 1 : 11-7.

30. De Gennaro Colonna V, Bianchi M, Pascale V, Ferrario P, Morelli $F$, Pascale $W$, et al. Asymmetric dimethylarginine (ADMA): an endogenous inhibitor of nitric oxide synthase and a novel cardiovascular risk molecule. Med Sci Monit 2009; 15: 91-101.

31. Welch GN, Loscalzo J. Homocysteine and atherothrombosis. N Engl J Med 1998; 338: 1042-50.

32. Dillon MC, Opris DC, Kopanczyk R, Lickliter J, Cornwell HN, Bridges EG, et al. Detection of homocysteine and C-reactive protein in the saliva of healthy adults: comparison with blood levels. Biomark Insights 2010; 5: 57-61.

33. Joseph R, Nath SG, Joseraj MG. Elevated plasma homocysteine levels in chronic periodontitis: a hospital-based case-control study. J Periodontol 2011; 82: 439-44.

34. Gerard C, Rollins BJ. Chemokines and disease. Nat Immunol 2001; 2: 108-15.

35. Charo IF, Taubman MB. Chemokines in the pathogenesis of vascular disease. Circ Res 2004; 95: 858-66.

36. Gemmell E, Marshall RI, Seymour GJ. Cytokines and prostaglandins in immune homeostasis and tissue destruction in periodontal disease. Periodontol 2000 1997; 14: 112-43.

37. Tonetti MS, Imboden MA, Gerber L, Lang NP, Laissue J, Mueller C. Localized expression of mRNA for phagocyte-specific chemotactic cytokines in human periodontal infections. Infect Immun 1994; 62: 4005-14.

38. Kurtiş B, Tüter $G$, Serdar M, Akdemir P, Uygur C, Firatli E, et al. Gingival crevicular fluid levels of monocyte chemoattractant protein-1 and tumor necrosis factor-alpha in patients with chronic and aggressive periodontitis. J Periodontol 2005; 76: 1849-55. 